DOI: http://dx.doi.org/10.18203/2320-1770.ijrcog20163450

\title{
A rare case of myiasis in a woman with genital prolapse
}

\section{Prabhleen Kaur*, Rita Ranjan, Ritu Goyal}

Department of Obstetrics and Gynaecology, Deen Dayal Upadhyay Hospital, New Delhi, India

Received: 23 June 2016

Accepted: 12 July 2016

\section{*Correspondence:}

Dr. Prabhleen Kaur,

E-mail: dr.prabhleenahuja@gmail.com

Copyright: ( $)$ the author(s), publisher and licensee Medip Academy. This is an open-access article distributed under the terms of the Creative Commons Attribution Non-Commercial License, which permits unrestricted non-commercial use, distribution, and reproduction in any medium, provided the original work is properly cited.

\begin{abstract}
Myiasis is an infestation by dipterous larva that thrives on host's living or necrotic tissue and cause massive tissue infection. We present a case of myiasis in a 65-year-old multiparous lady with procidentia. Her examination revealed a big excavatory ulcer on dependent part and cervix indwelled with maggots. About 40 to 50 such maggots were subsequently manually removed with a forceps. After conservative management, definitive surgical treatment for prolapsed uterus was done after healing of the ulcer, within three months. It is a very rare case as only a few reports have been previously published in literature.
\end{abstract}

Keywords: Myiasis, Uterus, Procidentia

\section{INTRODUCTION}

Myiasis is infestation by dipterous larva that thrives on host's living or necrotic tissue and cause massive tissue infection accompanied by severe inflammatory reaction and secondary bacterial infection. Cutaneous myiasis is the most common form, as the condition occurs in exposed areas of the body.

\section{CASE REPORT}

A 65 years old menopausal female for 15 years presented to us with the complaints of something coming out per vagina for 10 years, genital pruritus and foul smelling discharge for 1 months and maggot formation for 5 days. The prolapsed mass was initially small and gradually its size increased within past ten month. She neither had any symptoms of urinary/bowel discomfort nor had any painful lump in the groin due to inflamed lymph gland. She was multiparous with all four vaginal deliveries conducted at home by dai. Personal history revealed that she was very poor and uneducated dwelling in slum area, did not use to bath for several days, used to defecate in the open and lived in very unhygienic condition.
On examination she was ill looking, anxious and anemic, lean and thin and having poor nutrition status. She was normotensive, nondiabetic. Other systematic examination revealed no abnormality. Her pelvic examination revealed 'stage-IV' genitourinary prolapse according to POP-Q classification, with a big excavatory ulcer involving the whole of dependent part and external os. The prolapsed mass was partly distorted, edematous, hard and irreducible. There was profuse foul smelling discharge and maggot was seen in situ (Figure 1).

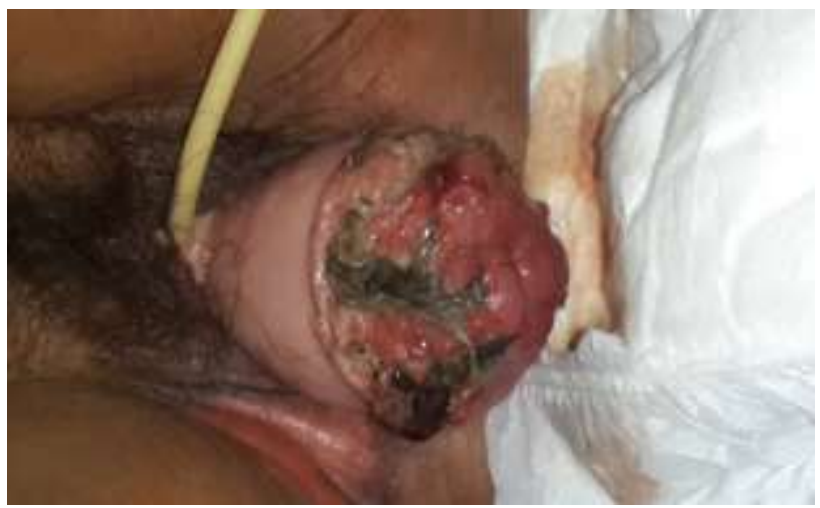

Figure 1: Damaged Prolapse Mass with Maggots. 
Baseline investigations were done $\mathrm{Hb} \%$ : $8.9 \mathrm{gm} . / \mathrm{dl}$, TLC-14000, neutrophilic leukocytosis, ESR-Raised 40, Serum creatinine: normal. RBS: $76.0 \mathrm{mg} / \mathrm{dl}$. X-ray chest P/A view: normal. USG whole abdomen: normal. ECG: normal.

At first conservatively management was done with daily dressing, ice packing to reduce the edema, application of turpentine oil to kill the maggots and was given parenteral broad spectrum antibiotic coverage. This forced many maggots to come out from deep inside the prolapsed uterus and about 45 to 50 such white larvae were removed manually with a forceps (Figure 2).

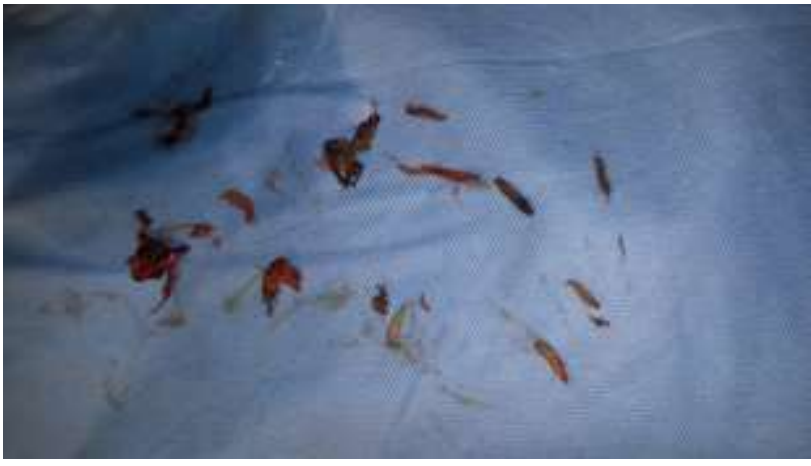

Figure 2: Manually removed Maggots with forceps.

In about 10 days the infection had subsided and edema was also reduced and prolapsed mass became soft and reducible and ulcer had started healing (Figure 3). Daily dressing and vaginal pack was continued for further healing of ulceration. After alleviating all the symptoms she was discharged after 2 weeks with instruction of twice daily douching packing and the advice to report to OPD after 1 month.

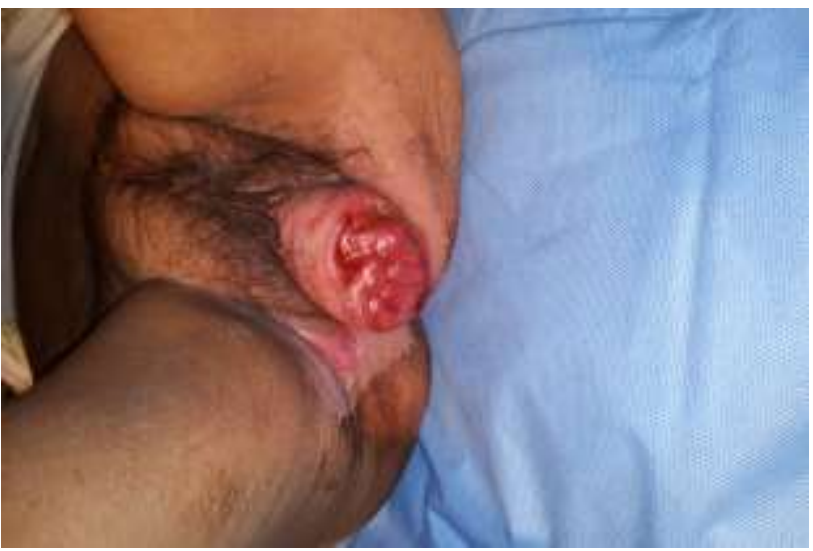

Figure 3: Infection and oedema subsided after conservative management and ulcer healing.

On follow up, after 1 month, she was found symptomless and free of any maggots; the ulcer had almost healed completely. She was counseled to undergo definitive surgical treatment for prolapsed uterus after one month and was advised to continue daily packing and was prescribing oral hematinic and supplements to improve anemia before surgery. Finally on her revisit after a month prolapsed uterus was found healthy for surgical management (Figure 4).

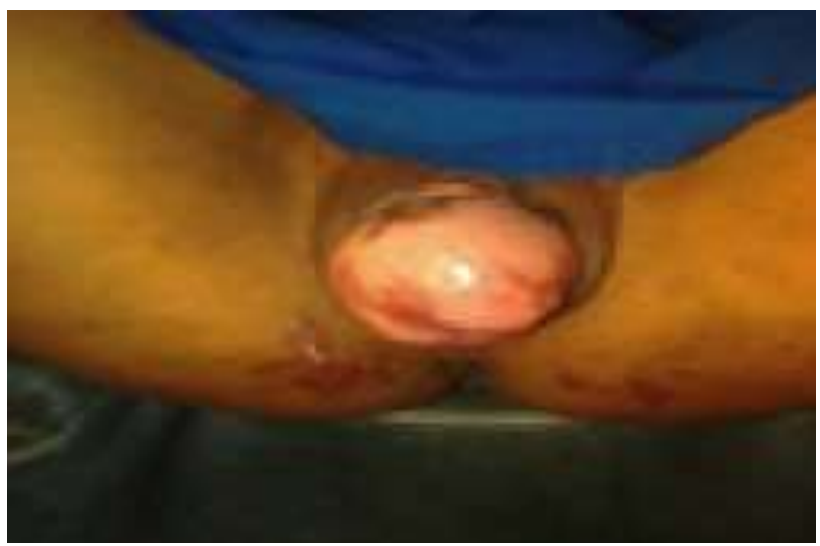

Figure 4: Prolapse uterus healthy for surgery after conservative management.

The specific management was done surgically by vaginal hysterectomy with pelvic floor repair. There were no post-operative complications and the patient was discharged on fifth post-operative day. She followed up after six weeks-having no complaint and her histopathological report too was normal.

\section{DISCUSSION}

Myiasis, a parasitic disease of humans and animals, is caused by the larvae of 50 fly species. The sites commonly involved are nose, ear, tracheostomy wound, face, gums and serous cavities. ${ }^{1}$ Genital myiasis is a rare occurrence. It is usually associated with poor general health and hygiene, restricted mobility, prolapsed and ulcerating lesions. ${ }^{2}$

The removal of indwelling maggots is very difficult and needs patience as these larvae penetrate deep into the tissue aided by sharp mouth hooks and anchoring intersegmental spines. Several irritant substance like chloroform and turpentine oil (1:4), ether, ethylene chloride, lidocaine etc., in literature were used in order to make the removal of larvae easy. 3,4 We had used turpentine oil to facilitate manual removal.

India's economy is growing very fast still roughly 1.2 billion people live in grinding poverty, with millions living in slums or on the sidewalk. Not only on economy, progression of life style is depends also on the education which enables a person to realize his or her personal hygiene; to think good for self or others; develop civic sense; judge independently to avail the healthcare facilities at proper time. ${ }^{5}$ But where more than $50 \%$ of girls fail to enroll in school then why would not such a rural, uneducated, poor woman would present with such a unique presentation like 'maggots in prolapsed uterus'? The real picture is the progression of economy and 
education remains concentrated among a few people of our country, eventually depriving the rest of them we are polluting our progress. This case emphasizes the need for good hygiene, sanitation and health education in tropical countries like India, with high fly population. ${ }^{6}$

\section{CONCLUSION}

Genital prolapse due to pelvic floor muscle weakness causes mechanical and functional symptoms. Improving our understanding and by making awareness about the etiology of prolapse should help to direct the treatment including non-surgical and surgical methods. Also its early detection and treatment can prevent various types of serious complications and help to reduce both morbidities and mortalities.

Funding: No funding sources Conflict of interest: None declared

Ethical approval: Not required

\section{REFERENCES}

1. Sultana MA, Akter M, Anam S. Procidencia with rare complication -a case report. KYAMC Journal. 2012;3(1):262-4.

2. Sabyasachi R, Subhadeep B, Hiralal K. Maggots in prolapsed uterus: polluted progress of life style. Medical J Armed Forces India. 2012;68:240-1.

3. Wadhwa V, Kharbanda P, Rai S. Urogenital myiasis due to Chrysomyia bezziana. Indian $\mathrm{J}$ Med Microbiol. 2006;24:70-1.

4. Passos M, Barreto N, Varella R. Penile myiasis: a case report. Sex Transm Infect. 2004;80:183-4.

5. Lopescosta P, Santos A, Pereira J. Myiasis in the uterine cavity of an elderly woman with a complete uterine prolapsed. Trans R Soc Trop Med Hyg. 2008;102:1058-60.

6. Manfrim A, Cury A, Demeneghi P. Nasal myiasis: case report and literature review. Int Arch Otorhinolaryngology. 2007;11:409.

Cite this article as: Kaur P, Ranjan R, Goyal R. A rare case of myiasis in a woman with genital prolapse. Int J Reprod Contracept Obstet Gynecol 2016;5:3590-2. 